\title{
Attitude of Under Graduate Students Towards E-Learning in West Bengal
}

\author{
Sunipa Samadder Nandy \\ Research Scholar, Department of Education, University of Kalyani, Kolkata India
}

\section{ABSTRACT}

With increasing high speed of internet connection ,opportunities has left a great impact on education . E-learning empowers one's interacting powers, without a doubt has fixed its roots in the field of education. The present study was conducted to find out the attitude towards e-learning among the under graduate student with respect to their gender, locality, academic stream. The major findings of the present study revealed that the college students have positive attitudes towards e-learning. There exists no significant difference in attitude towards e- learning between male and female and rural and urban under graduate students. There exists significant difference in attitude towards e-learning between arts and science under graduate students.

KEY WORDS: E-LEARNING, ATTITUDE TOWARDS, MOBILE LEARNING, BLENDED LEARNING.

\section{INTRODUCTION}

Nowadays living without 'Technology' is almost like a nightmare. We see the world today, it invariably means connected to the internet. In this technology era ,the sources of knowledge are many ways and quick approaches in a single click. E-learning is commonly referred to the uses of ICT for the purpose of added value in today's teaching and learning system. E-learning is an empowered by digital technology based on educational tools and systems than enable you to learn anywhere and at any time. In layman terms education contents store or recorded in electronic or digital mode a being transmitted through satellite or airwaves or cable or internet and reaches to students varies devices like computer, laptop, mobile, table and other few smart devices. Fegely .G. Alex (2020) pointed out that e-learning is the ways that

\section{ARTICLE INFORMATION}

Received 27th Oct 2020 Accepted after revision 12th Dec 2020 Print ISSN: 0974-6455 Online ISSN: 2321-4007 CODEN: BBRCBA

Thomson Reuters ISI Web of Science Clarivate Analytics USA and Crossref Indexed Journal

\section{Clarivate
Analytics}

NAAS Journal Score 2020 (4.31)

A Society of Science and Nature Publication,

Bhopal India 2020. All rights reserved.

Online Contents Available at: http//www.bbrc.in/

Doi: http://dx.doi.org/10.21786/bbrc/13.15/4 different disciplines and alternatives can focused on the study technically mediate education. E-learning is the method of providing delivering information, in such a way the students don't need to come to the classroom .

They can easily access all the data from any place which is convenient to them. E-learning can be self-paced or self-instruction and affixes media in the form of text, animation, streaming video, image, and audio. ComputerBased Training, Internet-Based Training, Web-Based Training have been used in e-learning (Yacob, Kadir, Zainudin and Zurairah, 2011). E-learning platform based on the learner-centred strategy which provides learner awareness in real time(EDUCO) and easy to make joint asynchronous annotations on documents (EDUCOSM). With the advent of student centred learning in selforganization and self-evolving (Kurhila, Miettinent, et.all 2004). There are some important models for the success of e-learning during creating and implementing strategies are student, course, students, subject, instructions, organizations, institutional ,policy, Government, region levels are the different e-learning strategies made. A pyramid is created by combining of all the e-learning strategies (Anotonia Berecz 2018). In addition, e-learning is the method where learning put together interactive

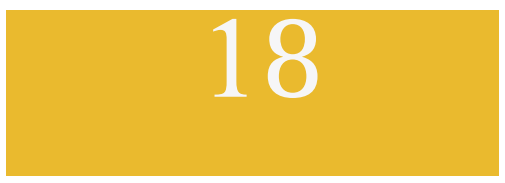


and collaborative by linking each learner and physically long experts, time and location flexibility, time and cost effectiveness for students(Shabha 2013).

Attitude is a psychological factor . It is affected on the students in several ways and it can shape their learning experience. Attitude comes into play in diverse way of the students in the field of their education . Attitude can be a deciding factor between success and unsuccess for an individual. As present society has became change day by day . It is advisable to change oneself to keep pace with the changing society .So people must have a positive attitude moving towards the changes. Psychological factor such as "attitude" is mentally concerned with aspects in students' acquisition (Budianto Langgenng 2011). Attitudes towards life of the students there are effects on the essential learning outcomes. Once characterized by intellectual skill communication , interpersonal skill and civic engagement (Kleebbua and Siriparp 2016). There are lots of silent factors for the benefit of e-learning during the stage of implementation in educational Institutions. Low preparedness can affected the use of e-learning facilities and it will lead to poor outcomes. (Al-Doub , Goodwin Al-Hunaiyan, 2009).

Review of Literature: Dhas Sign Jaya (2017) in her study they found that use of various e-learning tools and methodologies plays a important role to make the learning process more effective. Konwar Handique (2017) conducted a research and found that there was no significant differences between the attitudes of students of college students towards e-learning with respect to their gender,locality.. One way ANOVA Analysis indicated that way of learning, way of the studying and learning methods had significant impacts on the students' attitude towards e-learning. K.Khirade Santosh (2016), in his study, found that ther was a majority of the students have heard of e-learning platform. A huge interest among the students in acquiring education use of e-learning include internet accessand significant relationship between technology accessibility. Huang Meli, Liaw (2013) in their research publication, revealed that perceived satisfaction and usefulness in interactive learning environment was influenced by e-learning. Kar, Saha and Mondal (2014) conducted a research and result of the study that students' have high attitude towards e-learning and students attitude scores did not differ significantly with their personal variables such as gender, stream of study and residence. Saha, B \&t Mondal B.C (2014) i.e. "Attitude of University students towards e-learning in West Bengal" reported that university student's attitude towards e-learning is independent with reference to gender, residence and area of the study.

\section{Objectives of the Study}

The following objectives are laid down for the present study:

1. To study the nature of distribution of under graduate students on attitude towards e-Learning .

2. To study the difference in attitude of under graduate students towards e- learning with regard to gender
(Male/Female).

3. To study the difference in attitude of under graduate students towards e- learning with regard to locality (Urban/ Rural).

4. To study the difference in attitude of under graduate students towards e- learning with regard to academic stream (Arts/ Science).

\section{Hypotheses of the Study}

H01: There is no significant difference in attitude towards e- learning between male and female under graduate students.

H02: There is no significant difference in attitude towards e- learning between urban and rural under graduate students.

H03: There is no significant difference in attitude towards e- learning between arts and science under graduate students.

Rational of the Study: It is practically impossible to imagine a single moment without technology in this present era. E-Learning has become an integral part of traditional learning in majority of the educational institutions. E-learning foster great reciprocal action and collaboration in the students and it assists various learning activities. In order to keep pace with the era of rapid change, the direction of technological progress should not be overlooked. At the present time, we need to make our young generation learner aware of the rationale behind the use of e-learning and we have to prepare them to handle all the challenges which they may face in the current impending hurdles of technological life. The first thing to look at is how much attitude of the university students towards the use of e-learning. The significance of the study besides its effectiveness ,the under graduate level take plays an important role on the future direction. Any natural disaster such as in the pandemic has disrupted the normal lifestyle of the people across the world, virtual mode has come to the rescue. This is how those who have the attitude towards the e-learning who have been able to cope up with the situation.

\section{Operational Definition of Key Terms}

1. Under Graduate Students- It connotes the students studying in college of West Bengal .

2. Attitude towards e-Learning - In the present study attitude towards e-Learning refers to the individual's positive or negative feelings of participation in e-learning activities through online use.

3. Gender- It connotes the students male and female.

4. Stream- It refers the students belongs to arts and science stream.

5. Locality: It refers the student belongs to rural and urban area.

\section{Delimitations of the Study}

1. The study was restricted to only three district i.e .Kolkata, north 24 Parganas and Nadia District of the state. 
2. The study was delimited to the under graduate students only.

3. The study was confined to academic stream i.e arts and science.

\section{METHODOLOGY}

Design: The present study is descriptive survey in nature.

Sample: The sample consists of 200 students (200 male and 200 female) studying in under graduate students of West Bengal . Simple random sampling techniques has been used to collect the data.

Tool Used: Attitude Towards e-learning Scale developed by Dimpal Rani was used to collect the requisite data for the present study. This scale contains 65 statements. Out of sixty five items thirty eight were positive and twenty seven were negative items. The scale has four major areas, viz., 1. E- Learning interest, 2. Usefulness, 3. Ease of e-learning and 4. E-learning confidence. The 65 items (both positive and negative type) have been distributed in these four areas. The scale is a five - point scale viz. Strongly Agree, Agree, Undecided, Disagree and Strongly Disagree. Scoring was done separately for the positive and negative terms. A positive item carries the weights of 5, 4, 3, 2, 1 respectively for the categories of Strongly Agree, Agree, Undecided, Disagree and Strongly Disagree. The negative item is scored 1,2,3, 4 and 5 respectively for the Strongly Disagree , Disagree , Undecided, , Agree, Strongly Agree.
Reliability: The reliability of the scale was established by Test-Retest method. The coefficient of correlation found was +0.87 which is significant at 0.1 level of significance.

Validity: Content Validity of the items was ensured by rational logical analysis of the technology experts

Statistical Techniques Used: The researcher used the statistical techniques like Mean, standard deviation and ' $t$ '-test, etc for the shake of the fulfil the hypothesis of the study. The analysed results are presented in the following tables under different headings.

Analysis And Interpretation: The objective - wise analysis of collected data for the study are presented below:

\section{Studying the Nature of Distribution of Scores:}

Objective1 : To study the nature of distribution of under graduate students on attitude towards e-Learning

H01: There is no significant difference in attitude towards e- learning between male and female under graduate students. After analysing the collected data the researcher found the following result regarding the different nature of distribution of under graduate students on attitude towards e-learning.

E-Learning Among Under Graduate Students With Respect To Gender

\begin{tabular}{|c|c|c|c|c|c|c|}
\hline \multirow{2}{*}{$\begin{array}{l}\text { Class } \\
\text { Interval }\end{array}$} & \multirow[b]{2}{*}{$\begin{array}{c}\text { Male } \\
\text { percentage }\end{array}$} & \multirow[b]{2}{*}{$\begin{array}{c}\text { Male } \\
\text { percentage }\end{array}$} & \multicolumn{2}{|c|}{ Frequency } & \multirow[b]{2}{*}{$\begin{array}{c}\text { Total Frequency } \\
\text { (Male/Female) }\end{array}$} & \multirow[t]{2}{*}{ Total } \\
\hline & & & Female & $\begin{array}{c}\text { Female } \\
\text { Percentage }\end{array}$ & & \\
\hline $300-319$ & 3 & $1.50 \%$ & 0 & 0 & 3 & $0.75 \%$ \\
\hline $280-299$ & 5 & $2.50 \%$ & 6 & $3.00 \%$ & 11 & $2.75 \%$ \\
\hline $260-279$ & 15 & $7.50 \%$ & 14 & $7.00 \%$ & 29 & $7.25 \%$ \\
\hline $240-259$ & 43 & $21.50 \%$ & 45 & $22.00 \%$ & 88 & $22 \%$ \\
\hline $220-239$ & 69 & $34.50 \%$ & 68 & $34.00 \%$ & 137 & $34.25 \%$ \\
\hline $200-219$ & 46 & $23.00 \%$ & 46 & $23.00 \%$ & 92 & $23 \%$ \\
\hline 180-199 & 18 & $9.00 \%$ & 20 & $10.00 \%$ & 38 & $9.50 \%$ \\
\hline 160-179 & 0 & 0 & 1 & $0.50 \%$ & 1 & $0.25 \%$ \\
\hline $140-159$ & 0 & 0 & 0 & 0 & 0 & 0 \\
\hline $120-139$ & 0 & 0 & 0 & 0 & 0 & 0 \\
\hline $100-119$ & 1 & $0.50 \%$ & 0 & 0 & 1 & $0.25 \%$ \\
\hline Total & 200 & $100 \%$ & 200 & $100 \%$ & 400 & $100 \%$ \\
\hline
\end{tabular}

Interpretation: It is revealed from frequency distributions for male and female sample given in Table 1 and corresponding bar diagram given in Figures 1 that the scores on the variable of e-learning are distributed over a range of 196 for male and 134 for female sample. Thus, it may be said that the under graduate students differ in their level of e-learning. Hence, the hypotheses that "male college students do not differ in their level of e-learning"; "female under graduate students do not differ in their level of e-learning" are rejected. This is evident from the fact that 88.00 and 89.50 per cent subject fall between the scores 180 to 259 for the male 
and female sample respectively indicating almost similar concentration of scores in a limited range.

Figure 1: Bar Diagrams Based upon Frequency Distributions for Male, Female and Total Sample of under graduate students for the Scores on e-Learning

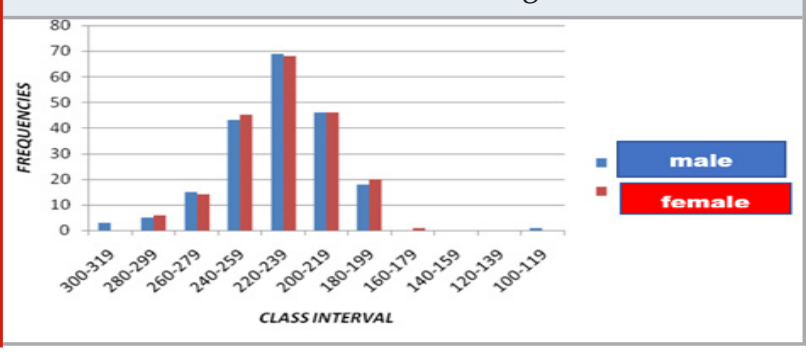

Interpretation: It is revealed from frequency distributions for rural and urban sample given in Table 2 and corresponding bar diagrams given in Figures 2 that the scores on the variable of e-learning are distributed over a range of 133 for rural and 188 for urban sample. Thus, it may be said that the under graduate students differ in their level of e-learning. Hence, the hypotheses that "Rural under graduate students do not differ in their level of e-learning"; "urban under graduate students do not differ in their level of e-learning" are rejected. This is evident from the fact that 90.50 and 87.50 per cent subjects fall between the scores 180 to 259 for the rural and urban sample respectively indicating almost similar concentration of scores in a limited range.

\begin{tabular}{|c|c|c|c|c|c|c|}
\hline \multirow{2}{*}{$\begin{array}{l}\text { Class } \\
\text { Interval }\end{array}$} & \multirow[b]{2}{*}{ Rural } & \multirow[b]{2}{*}{$\begin{array}{c}\text { Rural } \\
\text { percentage }\end{array}$} & \multicolumn{2}{|c|}{ Frequency } & \multirow[b]{2}{*}{$\begin{array}{c}\text { Total } \\
\text { Frequency } \\
\text { of locality }\end{array}$} & \multirow{2}{*}{$\begin{array}{c}\text { Total } \\
\text { Percentage } \\
\text { of } \\
\text { locality }\end{array}$} \\
\hline & & & Urban & $\begin{array}{c}\text { Urban } \\
\text { Percentage }\end{array}$ & & \\
\hline $300-319$ & 1 & $0.50 \%$ & 2 & $1.00 \%$ & 3 & $0.75 \%$ \\
\hline 280-299 & 3 & $1.50 \%$ & 7 & $3.50 \%$ & 10 & $2.50 \%$ \\
\hline $260-279$ & 15 & $7.50 \%$ & 14 & $7.00 \%$ & 29 & $7.25 \%$ \\
\hline $240-259$ & 43 & $21.50 \%$ & 45 & $22.50 \%$ & 88 & $22 \%$ \\
\hline $220-239$ & 69 & $34.50 \%$ & 68 & $8.50 \%$ & 137 & $34.25 \%$ \\
\hline $200-219$ & 47 & $23.50 \%$ & 45 & $0.50 \%$ & 92 & $23 \%$ \\
\hline 180-199 & 22 & $11.00 \%$ & 17 & $0.00 \%$ & 39 & $9.75 \%$ \\
\hline 160-179 & 0 & 0 & 1 & $0.50 \%$ & 1 & $0.25 \%$ \\
\hline $140-159$ & 0 & 0 & 0 & $0.00 \%$ & 0 & $0.00 \%$ \\
\hline 120-139 & 0 & 0 & 0 & $0.00 \%$ & 0 & $0.00 \%$ \\
\hline $100-119$ & 0 & 0 & 1 & $0.50 \%$ & 1 & $0.25 \%$ \\
\hline Total & 200 & $100 \%$ & 200 & $100 \%$ & 400 & $100 \%$ \\
\hline
\end{tabular}

Figure 2: Bar Diagrams Based upon Frequency Distributions for Rural and Urban Sample o college students for the Scores on eLearning

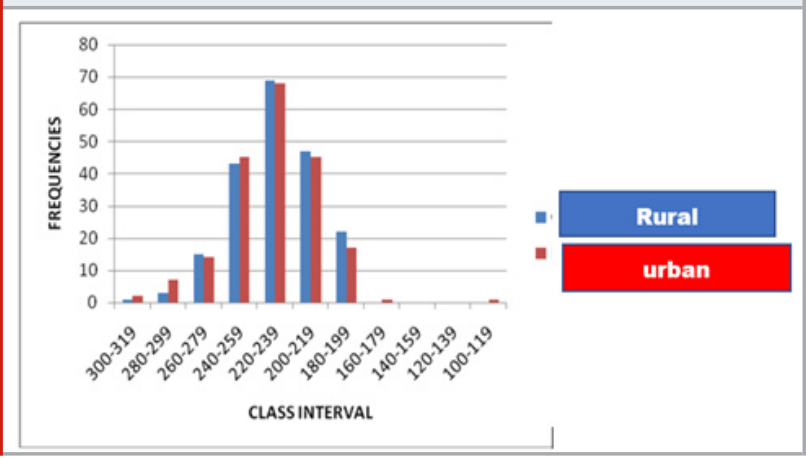

Interpretation: It is revealed from frequency distributions for arts ,science and total academic Stream of the sample given in Table 3 and corresponding bar diagrams given in Figures 3. that the scores on the variable of e-learning are distributed over a range of 196 for arts 115 for science and 196 for the total academic stream of the sample. Thus, it may be said that the under graduate students differ in their level of e-learning. Hence, the hypotheses that "arts under graduate students do not differ in their level of attitude towards e-learning"; "science under graduate students do not differ in their level of attitude towards e-learning" and "Total Academic stream of the sample of under graduate students do not differ in their level of attitude towards e-learning" are rejected. This is evident from the fact that $88.50,89.50$ and 89.00 per cent subjects fall between the scores 180 to 259 for the arts ,science and total Academic stream of the sample respectively indicating almost similar concentration of scores in a limited range.

It is revealed from Table 3. that t-value came out to be 0.07 , which is not significant. This indicates that male and female under graduate students do not differ significantly with respect to their mean scores on e-learning. Hence, the hypothesis that "Male and Female under graduate students do not differ significantly with respect to 
their attitude towards e-learning" is accepted. Hence, it may be inferred that male and female under graduate students exhibit more or less similar attitude towards e-learning. Such data for its better understanding have been presented in figure 4 in the form of bar diagram.

Table 3. Distribution of Scores on Academic stream (arts/ Science) for under graduate Students on the Variable 'e-Learning'

\begin{tabular}{|c|c|c|c|c|c|c|}
\hline \multirow{2}{*}{$\begin{array}{l}\text { Class } \\
\text { Interval }\end{array}$} & \multirow[b]{2}{*}{ Arts } & \multirow[b]{2}{*}{$\begin{array}{c}\text { Arts } \\
\text { (F) } \\
\text { percentage }\end{array}$} & \multicolumn{2}{|c|}{ Frequency } & \multirow[b]{2}{*}{$\begin{array}{c}\text { Total } \\
\text { Frequency } \\
\text { of academic } \\
\text { stream }\end{array}$} & \multirow[b]{2}{*}{$\begin{array}{c}\text { Total } \\
\text { Percentage } \\
\text { of } \\
\text { Academic } \\
\text { stream }\end{array}$} \\
\hline & & & Science & $\begin{array}{c}\text { Science } \\
\text { (F) } \\
\text { Percentage }\end{array}$ & & \\
\hline $300-319$ & 3 & $1.50 \%$ & 0 & 0 & 3 & $0.75 \%$ \\
\hline 280-299 & 4 & $2.00 \%$ & 6 & $3.00 \%$ & 10 & $2.50 \%$ \\
\hline $260-279$ & 14 & $7.00 \%$ & 15 & $7.50 \%$ & 29 & $7.25 \%$ \\
\hline $240-259$ & 39 & $19.50 \%$ & 49 & $24.50 \%$ & 88 & $22.00 \%$ \\
\hline 220--239 & 56 & $28.00 \%$ & 81 & $40.50 \%$ & 137 & $34.25 \%$ \\
\hline $200-219$ & 54 & $27.00 \%$ & 38 & $19.00 \%$ & 92 & $23.00 \%$ \\
\hline 180-199 & 28 & $14.00 \%$ & 11 & $5.50 \%$ & 39 & $9.75 \%$ \\
\hline $160-179$ & 1 & $0.50 \%$ & 0 & 0 & 1 & $0.25 \%$ \\
\hline $140-159$ & 0 & 0 & 0 & 0 & 0 & 0 \\
\hline 120-139 & 0 & 0 & 0 & 0 & 0 & 0 \\
\hline $100-119$ & 1 & $0.50 \%$ & 0 & 0 & 1 & $0.25 \%$ \\
\hline Total & 200 & $100 \%$ & 200 & $100 \%$ & 400 & $100 \%$ \\
\hline
\end{tabular}

Figure 3: Bar Diagrams Based upon Frequency Distributions for Academic Stream (arts/ science )Total Sample of under graduate Students for the Scores on e-Learning

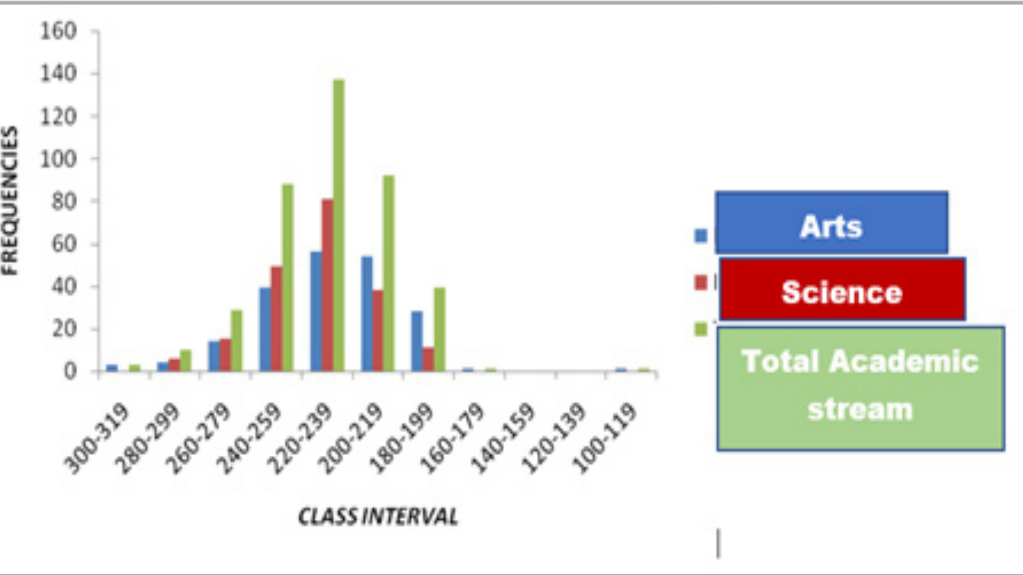

Table 4. t-value for Gender (male and female) under graduate students in respect of the variable of e-Learning

\begin{tabular}{c|c|c|c|c|c|c}
\hline Gender & $\mathrm{N}$ & Mean & SD & SEm & df & t- value \\
\hline Male & 200 & 230.20 & 25.72 & 1.82 & 398 & $\begin{array}{c}0.07 \\
\text { NS }\end{array}$ \\
\hline Female & 200 & 230.02 & 23.72 & 1.68 & & \\
\hline
\end{tabular}

$\mathrm{NS}=$ not significant

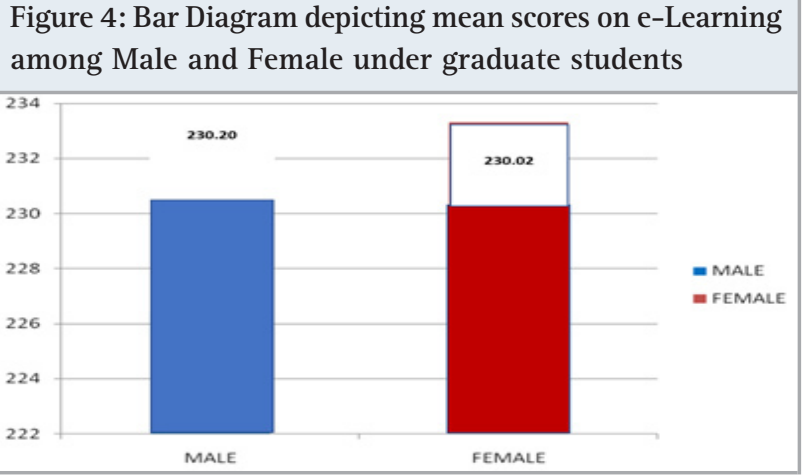


It is revealed from Table 4 that t-value came out to be 0.45 , which is not significant. This indicates that Rural and Urban under graduate students do not differ significantly with respect to their mean scores on e-learning. Hence, the hypothesis that "Rural and Urban under graduate students do not differ significantly with respect to their attitude towards e-learning" is accepted. Hence, it may be inferred that Rural and Urban under graduate students exhibit more or less similar attitude towards e-learning. Such data for its better understanding have been presented in figure 5 . in the form of bar diagram.

Table 5. t-value for Locality (rural and urban) under graduate students in respect of the variable of e-Learning

\begin{tabular}{|l|l|c|c|c|c|c|}
\hline locality & $\mathrm{N}$ & Mean & SD & SEm & df & t-value \\
\hline Rural & 200 & 229.32 & 23.16 & 1.63 & 398 & $\begin{array}{c}0.45 \\
\text { NS }\end{array}$ \\
\hline Urban & 200 & 230.41 & 26.02 & 1.85 & & \\
\hline
\end{tabular}

NS= Not Significant

Figure 5: Bar Diagram depicting mean scores on e-Learning among Rural and Urban under graduate students

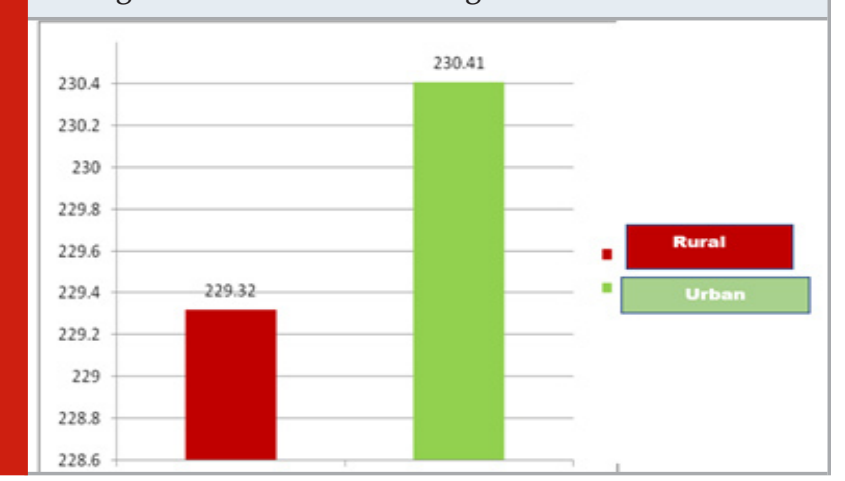

It is revealed from Table 6 . that t-value came out to be 2.81 , which is significant at 0.01 level of confidence. This indicates that arts and science under graduate students differ significantly with respect to their mean scores on e-learning. Hence, the hypothesis that "arts and science under graduate students do not differ significantly with respect to their attitude towards e-learning" is rejected. Since, the mean score on e-learning is higher for science (233.30) as compared to arts (226.43), it may be inferred that science under graduate students exhibit significantly higher attitude towards e-learning in comparison to the arts. Such data for its better understanding have been presented in figure 6 . in the form of bar diagram.

Findings of the Study: The major findings of the present study are as follows:

- The study revealed that the s under graduate students have positive attitudes towards e-learning.

- There exists no significant difference in attitude
Table 6. $\mathrm{t}$-value for Academic Stream (Arts and Science) under graduate students in respect of the variable of e-Learning

\begin{tabular}{|l|c|c|c|c|c|c|}
\hline $\begin{array}{l}\text { Academic } \\
\text { Stream }\end{array}$ & $\mathrm{N}$ & Mean & SD & SEm & df & t-value \\
\hline Arts & 200 & 226.43 & 27.50 & 1.92 & 398 & $2.81^{* *}$ \\
\hline Urban & 200 & 233.30 & 21.32 & 1.51 & & \\
\hline
\end{tabular}

**Significant at the 0,01level of confidence

Figure 6: Bar Diagram depicting mean scores on e-Learning among arts and science college students

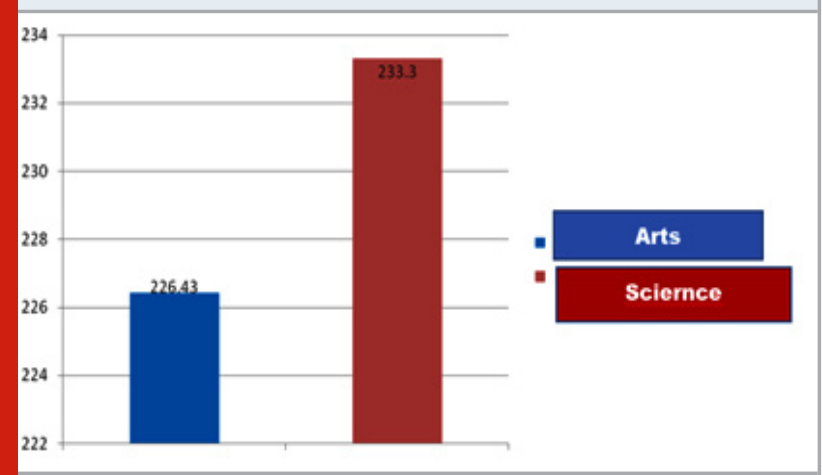

towards e- learning between male and female under graduate students.

- There exists no significant difference in attitude towards e- learning between urban and rural under graduate students.

- There exists significant difference in attitude towards e-learning between arts and science under graduate students.

\section{CONCLUSION}

From the above study investigator arrived that the attitude of under graduate students towards e-learning is independently with regards to gender and locality. Also revealed that the academic stream differ significantly with respect to their attitude towards e-learning. As the under graduate students attitude towards e-learning have been found to be very high among under graduate students, it is expected that they are ready to take opportunity of online learning mode.

Educational Implication: The study will be helpful for orienting align workshops, training programmes for under graduate students should be organized for developing their attitude towards e-Learning. The teachers and parents should motivate the students to get up to date information by using e-Learning. Teachers uses the blended learning method during the class sessions. Storyboards are great way to beneficial for the learners. It can help visual ideas, in a way interest to the learners. 


\section{Suggestion}

1. The objectives of the curriculum should be fulfilled through e-learning course.

2. There are myriad e-learning tools are allow that keep track accessible anywhere and anytime learning in comprehensive.

3. Develop a productive content plan on e-learning and plan should be outline all of the basics of e-learning strategies and target learners.

4. Productive e-learning is not just about providing information for learner instead motivated them .

5. Learners easily optimizing by mobile. As a result learner who have not computer or laptop like expensive gadgets they also can learn from the use of the mobile data.

6. Constantly boost up learner's to engagement with the real - incentives for productive learning.

\section{REFERENCES}

Al-Doub, Eisa; Goodwin, Robert and Al-Hunaiyyam (2008). Students' Attitude towards E-learning in Kuwait's Higher EducationInstitutions.https://www. researchgate.net/profile/Ahmed_AlHunaiyyan/ publication/238742438_Students'_Attitudes_Toward_ Elearning_in_Kuwait's_Higher_Education_Institutions/ links/55d7046908ae d6a199a51acd.pdf dated on 14-062017

Bhatia, R. P (2011).Features and Effectiveness of E-learning Tools, Global Journal of Business Management and Information Technology, Vol 1, No 1 pp. 1-7

Drigas, A. S., Tagoulis, A. Kyragianni, P., Nikolopoulos, P. and Kalomoirakis, D.An E-learning Platform for Multiform and Interactive Education of Scholars in Greek Paleography, Proc. ACM Symp. International Conference on Distance Learning and Web Engineering, ACM Press, Aug. 2005, pp. 90-94.

Fang, L. (2007, September). Perceiving the Useful, Enjoyable and Effective: A case study of the E-learning experience of tertiary students in Singapore. Educational Media International, 44(3), 237-253. Retrieved January 14, 2009.

Hamburg, I., Lindecke, C., \&t ten Thij, H. (2003). Social aspects of e-learning and blending learning methods. In Proceedings of the fourth European conference on E-commerce, Ework, E-learning, E-health, E-banking, E-business, on-line services, virtual institutes, and their influences on the economic and social environment (E-Comm-Line) (pp. 11-15).

Ingec, Sebnem Kandil (2015). Investigation on Students' Attitude towards elearning in terms of different variablesA case study in a technical and vocational High school for girls. Educational Research and Reviews.10. 81-91. Retrieved from http://www.academicjournals.org/ journal/ERR/article-full-textpdf/27E7E0E49496 dated on 23-05-2017

Liaw, S.S and Huang, H.M. (2011). A study of investigating learners attitudes toward e-learning, 5th International Conference on Distance Learning and Education, IPCSIT vol.12, IACSIT Press, Singapore.

Mehra, Vandana and Omidian, Faranak (2011). Examining Students' Attitude Towards E-learning: A Case from India: Malaysian Journal of Educational Technology. 11(2). 13-18.

Thurmond, V. A., \& Wambach, K. (2004). Understanding interactions in distance education: a review of the literature. Journal of Instructional Technology and Distance Learning, 1, 9- 33. WorldWideLearn (2007): The World's Premier Online Directory of Education, accessed May, 2008 from http://www.worldwidelearn. com/E-learning-essentials/E-learning-types.htm Yaghoubi, J. Iraj Malekmohammadi, Hooshang Iravani , Mohammad Attaran and Ahmad Gheidi (2008). Virtual students' perceptions of E-learning in Iran. The Turkish Online Journal of Educational Technology, 7(3). . Retrieved January 10, 2009. 